\title{
RIVERS, REGULATION AND RESTORATION: LAND USE HISTORY OF FLOODPLAINS IN A PERI-URBAN LANDSCAPE IN LUXEMBOURG, 1777 - 2000
}

\author{
Harald Schaich $^{1}$, Jacques Karier ${ }^{2}$, Werner Konold ${ }^{1}$
}

Received 8 February 2011; Accepted 16 December 2011

\begin{abstract}
This paper discusses the historical changes to and the uses of floodplain landscapes in Luxembourg from $1770-2000$ as a case study of a region with a rural past and a peri-urban present. Based on the historical landscape analysis approach, the study comprises historical evidence of written, cartographic and oral sources collected at a regional (Gutland) and a local (Syr Valley) level. The floodplains investigated were old cultural landscapes, shaped by agriculture, livestock husbandry, river regulation measures, land improvement, milling, navigation, mining and fisheries. Landscape change has been characterised by different periods of intensity, however it was not until the last century that these changes had a large-scale impact, inducing a complete loss of several ecological and socio-economic functions. A historical perspective of local landscape conditions and land use change is needed to maintain landscape identity in a contemporary peri-urban environment, and to base planning and restoration activities on reliable data.
\end{abstract}

Keywords: cultural landscapes, landscape planning, landscape history, land use change, river regulation, urban-rural fringe, ecological restoration, wetlands, Europe

Zusammenfassung: Dieser Beitrag diskutiert den Wandel von und die historischen Nutzungen in Auenlandschaften in Luxemburg von 1770-2000 als Fallstudie einer Region mit einer ländlichen Vergangenheit und einer peri-urbanen Gegenwart. Mit Hilfe einer historischen Landschaftsanalyse werden in der Studie historische Daten aus schriftlichen, kartografischen und mündlichen Quellen einbezogen und auf einer regionalen (Gutland) und einer lokalen räumlichen Ebene ausgewertet. Die untersuchten Auen sind alte Kulturlandschaften, die von der Landwirtschaft, der Viehhaltung, Flussausbau- und Entwässerungsmaßnahmen, der Mühlenwirtschaft, der Schifffahrt, dem Abbau von Rohstoffen und der Fischerei geformt wurden. Der Landschaftswandel lief dabei in mehreren Perioden mit unterschiedlicher Intensität ab. Allerdings hatte dieser Wandel erst im vergangenen Jahrhundert einen großmaßstäblichen Einfluss, der einen Verlust von verschiedenen ökologischen und

\footnotetext{
1 Dr. Harald Schaich, Prof. Dr. Werner Konold, Institute for Landscape Management, Faculty of Forest and Environmental Science, University of Freiburg, Tennenbacher Str. 4, D-79106 Freiburg, Germany, E-mails: harald.schaich@landespflege.uni-freiburg.de,werner.konold@landespflege.uni-freiburg.de

2 Jacques Karier (Dipl.-For.), Lycée Technique Agricole, 72, Avenue Salentiny, L-9080 Ettelbruck, Luxembourg, Email: jacques.karier@education.lu
} 
sozio-ökonomischen Landschaftsfunktionen mit sich brachte. Die historische Perspektive von lokalen Landschaftszuständen und des Landnutzungswandels ist notwendig, um Landschaftsfunktionen in der heutigen peri-urbanen Umgebung aufrecht zu erhalten und die Raumplanung und Renaturierungsvorhaben auf verlässliche Daten zu stützen.

Schlüsselwörter: Kulturlandschaft, Landschaftsplanung, Landschaftsgeschichte, Landnutzungswandel, Melioration, Renaturierung, Feuchtgrünland, Europa

\section{Introduction}

The phenomena of urbanisation and peri-urbanisation are rapid and pervasive forms of land use change in Europe (Paul \& Meyer, 2001). In peri-urban environments in particular, agriculture and urbanisation are the two major causes of floodplain impairment that simultaneously act as threats to these ecosystems. These two current threats, and the long history of human intervention, are responsible for the virtual absence of intact floodplain systems in Europe (Tockner \& Stanford, 2002). However, semi-natural floodplains are indispensable for the protection of biodiversity within Europe's cultural landscapes (Joyce \& Wade, 1998). The high biodiversity of floodplains is promoted by river dynamics and flood pulsing, the variability of vegetation and landscape structures, and traditionally extensive (as opposed to 'intensive') land use practices (Ward et al., 2002). Floodplains provide crucial services in cultural landscapes such as the regulation of water and matter flows, sediment and pollutant retention, and filtration effects (Konold, 2007). In peri-urban environments in particular, floodplains must support new socio-economic functions in addition to agricultural land use and conservation interests. They serve as recreational areas for the urban population and, as building sites for industry and residential areas, they are required to retain water and buffer the effects of floods as well as to provide potable groundwater (Hale \& Adams, 2007). In this 'contested environment', sound floodplain restoration is necessary for the rehabilitation of key ecological functions, to stop biodiversity loss and to serve new socio-economic functions.

Owing to the almost complete absence of pristine floodplain habitats in Europe and the long duration of human intervention in floodplain areas, the reconstruction of original floodplain environments as reference conditions for restoration measures is highly theoretical (Swart et al., 2001, Wohl, 2005). Furthermore, associated with this long history of human interference are ecological losses and the impairment of flooding and river dynamics on the one hand and the rise of historical, cultural, economic and "new" ecological values on the other (Haase, 2003). Human use has shaped new, cultural floodplain types and left landscape relics, such as mill buildings and old stone bridges, as well as cultural habitats, with certain habitat traditions such as mesophilic meadows (Konold, 1998, Pfadenhauer, 2001, Konold, 2005). New approaches in restoration ecology include the restoration of ecosystem functions and services as targets for restoration measures, often accomplished through measures and management regimes that mimic natural and traditional disturbances (Ehrenfeld, 2000, Pykälä, 2000). Landscape histories can be used to decipher past land use and to relate it to ecosystem functioning, thereby contributing to an understanding of landscape dynamics and the interactions of landscape elements (Swetnam et al., 1999, SER, 2004).

The objective of this study was to develop a history of land use changes affecting floodplains in riparian landscapes in Luxembourg that were historically rural but, being situated in the vicinity of a growing urban centre, are now peri-urban. The underlying hypothesis is that although overall land use change developed in a relatively uniform manner across the floodplains of Central Europe, the intensity of several types of land use and their impacts on the floodplain landscapes varied considerably at the local scale. It is therefore necessary to include the results of local and regional land use histories in the planning process for landscape development, conservation and restoration measures, especially in highly dynamic peri-urban environments. 
In particular, we aim to answer the following research questions:

- How did land use develop in the floodplain areas of the Gutland region in Luxembourg and what have been the major drivers for the rise or decline of certain types of land use?

- How did land use development and especially drainage efforts trigger changes in a distinct local floodplain landscape and the related stream ecosystems?

- What can regional and local land use histories contribute to the landscape and restoration planning process in a now peri-urban floodplain area?

Distinctive features of such peri-urban areas are rapid changes to land use, landscape structures and driving forces over the last century, a shortage of space and highly divergent land use interests. Luxembourg offers an ideal terrain to study the effects of a changing rural to peri-urban landscape because it boasts the highest percentage of population living in intermediately populated zones (nearly $50 \%$ compared to an average of $24 \%$ for Europe as a whole), the category that includes peri-urban environments (EUROSTAT, 1999). The Gutland region surrounding the city of Luxembourg, where the study is situated, incorporates rural characteristics within a predominantly urban structure that comprises small to medium size agglomerations. Data on historical land use, population and agricultural statistics, land ownership structure and land improvement were collected at two spatial levels - regional (Gutland) and local (Syr Valley: Schlammwiss-Aalbach).

\section{Study area}

\subsection{Regional level: Gutland region}

The hilly Gutland region is situated in the south-central part of the grand duchy of Luxembourg (see figure 1) and extends over $62 \%$ of the country's total area $\left(2,586 \mathrm{~km}^{2}\right)$. The undulating landscape is bordered by the foothills of the Ardennes to the northwest, the Mosel Valley to the east and the Minette lowlands to the south. The elevations range from $130 \mathrm{~m}$ in the river valleys to $400 \mathrm{~m}$ in the sandstone formations. Geologically, the area consists of a Mesozoic sequence of the Triassic with formations of Luxembourgian sandstone (Lower Triassic), limestone of shell fragments (Middle Triassic) and marl (Upper Triassic). Two principal soil types can be distinguished: a dry and nutrient-poor soil over sandstone parent material and heavy, waterlogged, clay and nutrient-rich soil over marl. The predominant land use types correspond with the prevailing soils, with high forest of different beech and oak associations found on the sandstone soils, and permanent grassland, and to a lesser degree arable land, on the keuper soils (Administration des Eaux et Forêts, 1995). The climate is temperate with mild, rainy winters and moderate, humid summers. The spectrum of water bodies (total length: 487 $\mathrm{km}$ ) ranges from small lowland streams (Syr) to navigable rivers (Mosel). The valley floors of Gutland's water courses are mostly broad and the river beds consist of loamy to pebbly substrates and are usually rich in underwater vegetation (Gerecke et al., 2005). The roots of settlement in the Gutland extend back to the Neolithic Age. The prime and strategic location of this region, with its proximity to significant commercial, political and religious centres and the routes joining them (e.g., the route between Treves and Metz), as well as the city of Luxembourg's impressive fortifications, prompted several periods of foreign rule by great European powers beginning in the $15^{\text {th }}$ century (Kreins, 1996).

\subsection{Local level: Schlammwiss-Aalbach (Syr Valley)}

The local study site, Schlammwiss-Aalbach, is situated in the floodplain of the upper Syr Valley and extends over 110 ha, crossing the territories of the three townships Betzdorf, Niederanven and Schuttrange (see figure 1). This stretch of the Syr slopes gently and forms a characteristic wide open valley with sides flaring outwards. The mean discharge of the Syr in September 1999 was $305 \mathrm{I} \mathrm{s}^{-1}$, judged to be representative of the usual summer discharge (Centre de Recherche Public, 2000). After a long history of human cultivation, open grassland dominates the floodplain landscape. The townships Betzdorf, Niederanven and Schuttrange developed in the shadow of the city of Luxembourg, though their differing proximities to the city resulted in an urban-rural gradient. Hence, they differ in their degree of peri-urbanity (Statec, 2007). Peri-urban areas can 
be defined according to two characteristics (Iaquinta \& Drescher, 2000, Caruso, 2005): (a) they are under an urban influence (functional link, commuting flows, primarily non-agricultural labour force) and (b) they exhibit a rural character (presence of an agricultural/forestry sector, relatively low population densities). The population density is highest in Schuttrange with 203 inhabitants per $\mathrm{km}^{2}$ and lowest in Betzdorf with 99 inhabitants per $\mathrm{km}^{2}$. In 2002, the majority of the working population was employed in the tertiary sector (Niederanven: $87 \%$, Betzdorf: $64 \%$ ). Most of the employees commute to the city of Luxembourg. However, a rural character is still maintained in the townships, as a vital part of the surface area is dedicated to the agriculture/forestry sector, for example, the total cultivated area ranges from 523 ha (Schuttrange) to 1,635 ha (Betzdorf).

\section{Material and methods}

Cultural landscapes, especially in the proximity of urban centres, are highly dynamic systems driven by human land use and natural processes. Historical sources documenting such changes often vary considerably in terms of their quantity and quality across time and space. In this study, therefore, multiple lines of evidence from different spatial levels were combined to ascertain the accuracy and quality of the interpretation of historical records for the landscape analysis (Schwineköper, 2000). The study was based on a combination of qualitative, quantitative and spatially explicit data from written, cartographic and oral primary sources and the analysis of secondary literature sources.

The period studied spanned the years 1777-2000 and incorporated two spatial scales a regional landscape level and a local riparian zone level. The results were structured at the regional scale in accordance with relevant land management practices to obtain an overview of the human interventions. The detailed case study at the local level was structured chronologically. Floodplain history is closely related to the governing regime and the major societal and technical changes over time. For this reason, the study of the local floodplain area was structured according to major periods and eras of change.

Narrative databases were constructed for both spatial levels, each for the collation of qualitative, quantitative and spatial historical evidence obtained from archives and libraries, as well as the information obtained from the secondary literature. Spatial data for the local level obtained from historical maps were compiled for the purposes of a comprehensive qualitative visual analysis as opposed to a quantitative GIS analysis. This approach was chosen because of a lack of cartographic sources and land use information for all time periods. Additionally, insights into land use practices within the last century on the local level were gained through indepth interviews, applying the oral history approach, with two established residents and former land managers (Fogerty, 2001). Data from primary sources were collected in the National Archive of Luxembourg (ANL), the National Library of Luxembourg (BNL), the Archives of the Luxembourg Forest Service (AEF), the Luxembourg Agricultural Administration (ASTA) and the Luxembourg Administration of Water Bodies (AGE), and finally the National Land Registry Office (ACT). The main sources included in the analysis are displayed in table 1 and are cited in the text using roman numerals. 

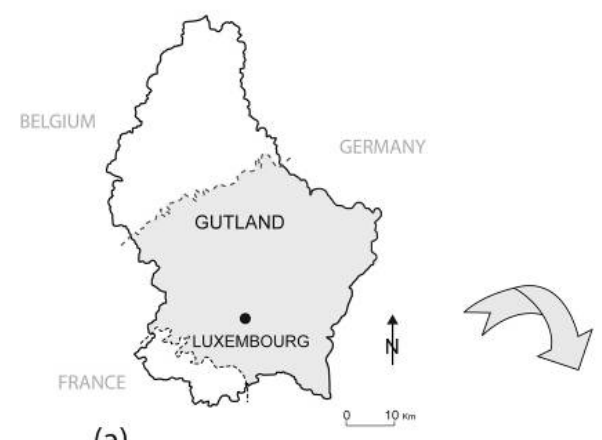

$0 \quad 10 \mathrm{~km}$

(a)

(c)

(b)
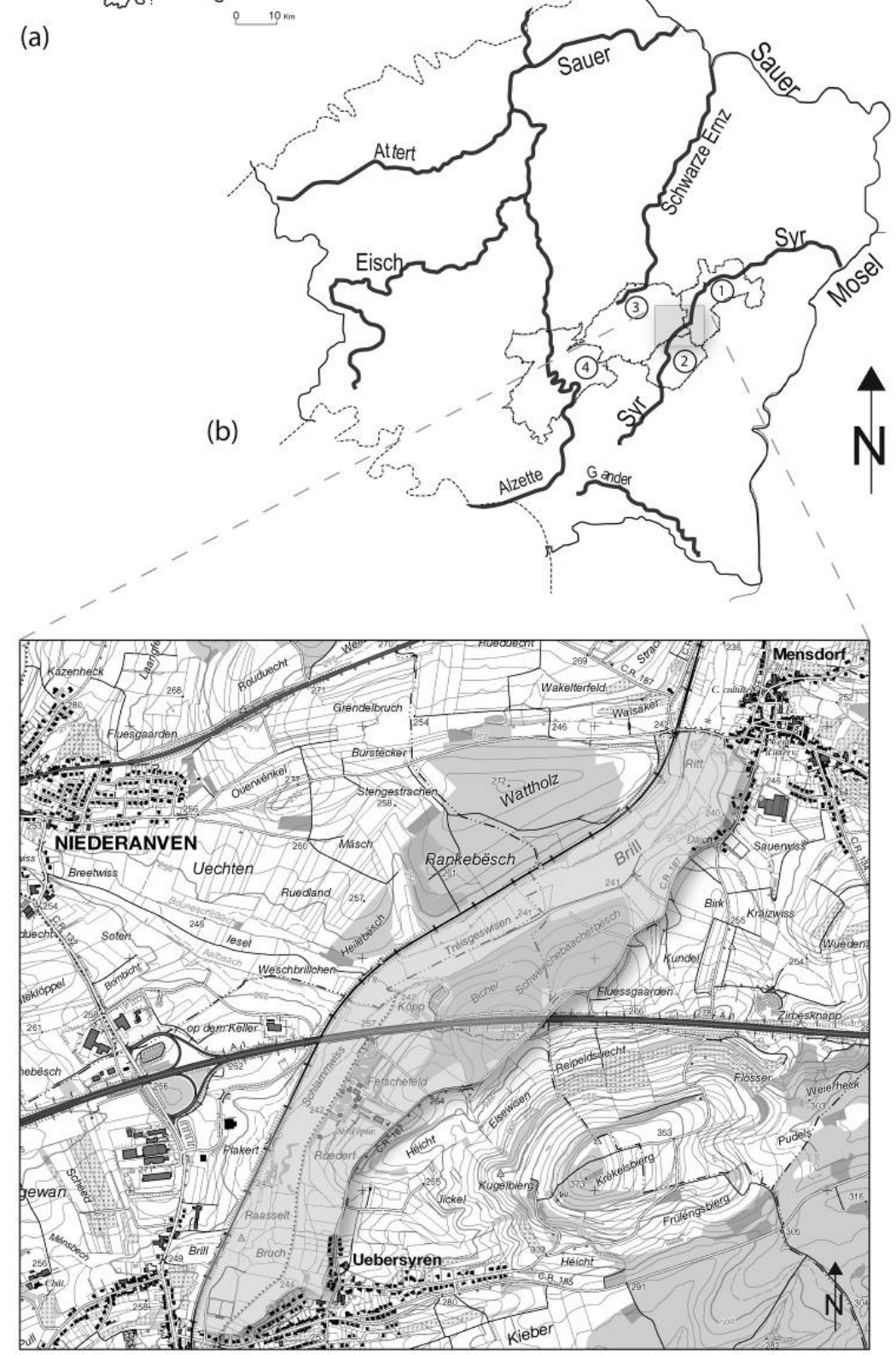

Fig 1. Study site location map: (a) Gutland region within the grand duchy of Luxembourg, (b) the Gutland with its most important water courses, the township boundaries of Betzdorf (1), Schuttrange (2), Niederanven (3) and the City of Luxembourg (4), and the location of the local study area along the River Syr, (c) the spatial extent of the local study site 'Schlammwiss-Aalbach' within the Syr floodplain (Map (c): (C) Administration du cadastre et de la topographie Luxembourg, excerpt of topographic map TC 18 (scale 1/20.000), permission from 19 ${ }^{\text {th }}$ April 2007). 


\begin{tabular}{|c|c|c|c|c|c|}
\hline SOURCE & YEAR & SPATIAL LEVEL & ARCHIVE & TYPE & CODE \\
\hline Administrative acts & $1600-1960$ & Regional, local & ANL, ASTA & $\begin{array}{l}\text { Documents and } \\
\text { manuscripts }\end{array}$ & {$[1]$} \\
\hline $\begin{array}{l}\text { Carte manuscrite des Pays- } \\
\text { Bas Autrichiens du général } \\
\text { Joseph de Ferraris }\end{array}$ & $1771-1778$ & Local & $A E F, B N L$ & Map and legend & [II] \\
\hline $\begin{array}{l}\text { Construction plans and } \\
\text { outlines }\end{array}$ & $1789-1878$ & Local & $\begin{array}{l}\text { ANL, AGE, } \\
\text { ASTA }\end{array}$ & Map & [III] \\
\hline Land registers & $\begin{array}{l}1771,1830 \\
1971,2005\end{array}$ & Regional, local & ACT & Map and legend & {$[\mathrm{IV}]$} \\
\hline Historical agricultural statistics & 1839-1889 & Regional & ASTA & Manuscript & [V] \\
\hline $\begin{array}{l}\text { Pamphlets by E. Lamort and } \\
\text { J. Enzweiler }\end{array}$ & 1891 & Regional, local & BNL & Manuscript & {$[\mathrm{VI}]$} \\
\hline $\begin{array}{l}\text { Documentation of land } \\
\text { improvements }\end{array}$ & $1883-1962$ & Local & AGE, ASTA & $\begin{array}{l}\text { Documents and } \\
\text { protocols }\end{array}$ & [VII] \\
\hline $\begin{array}{l}\text { Agricultural report of the } \\
\text { Reichsnährstand }\end{array}$ & 1941 & Local & ASTA & Manuscript & [VIII] \\
\hline Land managers (retired) & $1950-2006$ & Local & - & Interview & {$[\mathrm{IV}]$} \\
\hline
\end{tabular}

Tab 1. Most significant primary sources used ${ }^{3}$.

\section{Land use history in the floodplains of the Gutland}

\subsection{Settlements, population development and ownership structure}

Since the Neolithic Age, the broad floodplains of the Gutland region have been preferentially and permanently settled. The floodplains were completely cleared of forests in the $16^{\text {th }}$ century (Schmithüsen, 1940). Luxembourg was sparsely populated in the past, with 50 inhabitants per $\mathrm{km}^{2}$ in 1821 . Steady population growth began in the second half of the $19^{\text {th }}$ century, with the population density doubling by 1960 . After the 1960 s, population growth accelerated further as Luxembourg became one of the leading financial centres in Europe and home to several EU institutions. Current population density averages at 180 inhabitants per $\mathrm{km}^{2}$.

Until the $18^{\text {th }}$ century, the peasant economy in the Gutland was governed by feudalism (Schmithüsen, 1940). The landscape was a mixture of large estates owned by the nobility and clergy, large areas of commons with grazing rights, and numerous small plots. Following the French Revolution and a new law of succession (code civil), introduced when Luxembourg became a French department in 1795, the large estates were subdivided and grazing rights in fenced commons were abolished. The consequence of this was increased parcelling of the floodplain area with mean sizes decreasing from 0.38 ha in 1855 to 0.33 ha in 1889 (Kohl, 1925). The unclear distribution of land and the absence of infrastructure prompted the 'Flurzwang', which regulated when and how a peasant could manage his fields. The decrease in parcel size and the subsequent detailed regulation of land use also occurred in many other parts of Europe (Müller, 2005). By the end of the $19^{\text {th }}$ century, land improvement cooperatives installed field paths and lumped together the fields of individual owners [IV, see table 1], and during the $20^{\text {th }}$ century, the number of small parcels declined rapidly.

\subsection{Agriculture and livestock husbandry}

Until the mid $19^{\text {th }}$ century, the agricultural techniques employed in the Gutland had remained almost unchanged for a thousand years (Frisch, 2003). Agriculture was specialised in crop cultivation, and the crop area in the $19^{\text {th }}$ century was far greater than it is today [IV]. According to Gerlach (1990), arable land also dominated in those times in central Germany, accounting for $85-90 \%$ of the surface area in the watershed of the River Main, with few grasslands situated in the valley floor. Crop production mostly took place in the proximity of the Gutland settlements

\footnotetext{
${ }^{3}$ archive abbreviations are explained in the text
} 
and was organised according to a three-field-rotation system. Livestock was used for the provision of dung and as draught animals (Frisch, 1973). As in many other regions of central Europe, these few animals grazed the outer fields and the wet and unproductive floodplain wastelands, as well as the harvested fields (Poschlod \& Wallis de Vries, 2002). The 'grazing rights' ensured that livestock could feed in the floodplains, fallow land and the forests of different owners and those of several townships [V].

Land consolidation, the expansion of rail and road networks, subsequent trade in agricultural products, the development of mineral fertilisers and mechanisation brought about an end to the three-field system and the conversion of one third of the field area into meadows and pastures in the second half of the $19^{\text {th }}$ century (Kohl, 1925, Frisch, 2003). During this period, wasteland in the floodplains that was previously used as livestock pasture disappeared and was substituted by drained and meliorated meadows and pastures [l]. Similar developments took place in many lowland regions of southern Germany (Müller, 2005). The increasing importance of livestock husbandry and subsequently fodder production was demonstrated in a report by an agricultural commission from 1890 (Flammang, 1991):

"It is not enough to have a lot of livestock, for a profitable business it must be fed properly. The cleaning up of acid, swampy grasslands is ongoing; at all operations viewed during our visit, we observed land improvements brought about by levelling, drainage and irrigation."

\begin{tabular}{|c|c|c|c|c|}
\hline LAND USE & PERIOD & SPATIAL INFLUENCE & INTENSITY & IMPACTS \\
\hline \multirow[t]{2}{*}{ Agriculture } & $\begin{array}{l}\text { Until the } 19^{\text {th }} \\
\text { century }\end{array}$ & Local & Low & \multirow{2}{*}{$\begin{array}{l}\text { Erosion and sedimentation, } \\
\text { elimination of vegetation } \\
\text { structures, destruction of } \\
\text { habitats }\end{array}$} \\
\hline & $\begin{array}{l}\text { 19th century - } \\
\text { today }\end{array}$ & Local & High & \\
\hline \multirow[t]{2}{*}{ Fertilization } & Until 1850 & Local & Low & \multirow{2}{*}{$\begin{array}{l}\text { Transformation of vegetation, } \\
\text { nutrient accumulation, } \\
\text { elevated nutrient loads of } \\
\text { water bodies }\end{array}$} \\
\hline & 1850 - today & Widespread & $\begin{array}{l}\text { Intermediate } \\
\text { - high }\end{array}$ & \\
\hline Drift pasture & Until 1950 & Widespread & $\begin{array}{l}\text { Low - } \\
\text { intermediate }\end{array}$ & $\begin{array}{l}\text { Transformation of vegetation, } \\
\text { structural diversification }\end{array}$ \\
\hline Paddock pasture & 1900 - today & Local & High & $\begin{array}{l}\text { Transformation of vegetation, } \\
\text { elimination of vegetation } \\
\text { structures, nutrient } \\
\text { accumulation }\end{array}$ \\
\hline \multirow[t]{2}{*}{ Mowing } & Until 1950 & Local & Low & \multirow{2}{*}{$\begin{array}{l}\text { Transformation of vegetation, } \\
\text { elimination of vegetation } \\
\text { structures, nutrient deprivation }\end{array}$} \\
\hline & 1950 - today & Widespread & $\begin{array}{l}\text { Intermediate } \\
\text { - high }\end{array}$ & \\
\hline Meadow irrigation & unknown & Local & Low & $\begin{array}{l}\text { Installation of ditches, } \\
\text { Transformation of vegetation, } \\
\text { nutrient accumulation }\end{array}$ \\
\hline
\end{tabular}

Tab 2. Agricultural land uses and ecological impacts on floodplains in the Gutland region.

Floodplain meadows provided hay and were grazed in early spring and again after mowing in summer. The one cut mowing system prevailed across two thirds of Luxembourg's meadows at the end of the $19^{\text {th }}$ century (Schmithüsen, 1940). According to the grazing rights, the livestock herds of a township fed on the stubble of the mown meadows. Until the $19^{\text {th }}$ century, there were 'pasture cooperatives' operating between adjacent villages to facilitate the mutual use of pasture resources [I]. The meadows of the Gutland floodplains were naturally fertilized by floodwaters each spring and autumn, according to the discharge regime. In June 1893, the government allowed farmers to establish small barrages for selective meadow irrigation [I]. The agricultural use of the land and its impact on the floodplains is summarised in table 2.

\subsection{River regulation measures and land improvement}

River regulation and land improvement measures began in the central European lowlands as early as the end of the Thirty Years' War in 1648 (Gudermann, 2000), whereas in mountain 
areas these developments started much later, not occurring in the western Alps until 1829 (Girel et al., 1997). The first river development measures in the Gutland were implemented under the Austrian government in 1720 after an imperial ordinance was passed. In a single action, officers of the province were required to 'clean up' the trees and vegetation in the beds and along the sides of all the water courses in the province for flood protection purposes (Konsbruck, 1970). The cumulative damaging effects of floods also prompted a regulation stipulating vegetation clearance (mostly willow trees) along the River Alzette and deepening of the river bed along the River Alzette, issued by Empress Maria Theresia - an absolutist in the spirit of the Enlightenment - on $10^{\text {th }}$ October 1756 (Nicolay, 1938, Konsbruck, 1970). This 'cleaning' action between 1764 and 1766 completely altered the course of the River Alzette. The need for land improvement also arose during the reign of Maria Theresia who, in an ordinance from 1762 (Nicolay, 1938), sought to obtain 'new meadows'.

\begin{tabular}{|c|c|c|c|c|}
\hline INTERVENTION & PERIOD & SPATIAL INFLUENCE & INTENSITY & IMPACTS \\
\hline \multirow{2}{*}{$\begin{array}{l}\text { Sludge removal and } \\
\text { deepening of water } \\
\text { courses ('clean up') }\end{array}$} & $\begin{array}{l}18^{\text {th }}-\text { end of } 19^{\text {th }} \\
\text { century }\end{array}$ & Local & Low & \multirow{2}{*}{$\begin{array}{l}\text { Higher run-off erosion, } \\
\text { deepening of groundwater } \\
\text { table, destruction and creation } \\
\text { of habitats }\end{array}$} \\
\hline & $\begin{array}{l}19^{\text {th }}-\text { end of } 20^{\text {th }} \\
\text { century }\end{array}$ & Widespread & High & \\
\hline $\begin{array}{l}\text { Removal of coarse } \\
\text { woody debris } \\
\text { ('clean up') }\end{array}$ & $\begin{array}{l}18^{\text {th }}-\text { end of } 19^{\text {th }} \\
\text { century }\end{array}$ & Widespread & Intermediate & $\begin{array}{l}\text { Higher run-off velocity and } \\
\text { erosion, reduced river } \\
\text { dynamics, destruction of } \\
\text { habitats }\end{array}$ \\
\hline $\begin{array}{l}\text { Elimination of river } \\
\text { meanders }\end{array}$ & $\begin{array}{l}18^{\text {th }}-\text { end of } 19^{\text {th }} \\
\text { century }\end{array}$ & Local & Low & $\begin{array}{l}\text { Higher run-off velocity and } \\
\text { erosion, reduced river } \\
\text { dynamics, higher flood risk, } \\
\text { destruction of habitats }\end{array}$ \\
\hline Installation of dams & $\begin{array}{l}18^{\text {th }}-\text { end of } 19^{\text {th }} \\
\text { century }\end{array}$ & Local & Low & $\begin{array}{l}\text { Transformation of water } \\
\text { balance, cessation of natural } \\
\text { inundations, destruction and } \\
\text { creation of habitats }\end{array}$ \\
\hline $\begin{array}{l}\text { Straightening and } \\
\text { enlargement of } \\
\text { water courses ('river } \\
\text { regulation') }\end{array}$ & $\begin{array}{l}19^{\text {th }}-\text { end of } 20^{\text {th }} \\
\text { century }\end{array}$ & Widespread & High & $\begin{array}{l}\text { Transformation of water } \\
\text { balance, Higher run-off } \\
\text { velocity and erosion, reduced } \\
\text { river dynamics, higher flood } \\
\text { risk, destruction of habitats, } \\
\text { elimination of vegetation } \\
\text { structures }\end{array}$ \\
\hline $\begin{array}{l}\text { Vegetation removal } \\
\text { ('clean up') }\end{array}$ & $\begin{array}{l}19^{\text {th }}-\text { end of } 20^{\text {th }} \\
\text { century }\end{array}$ & Widespread & High & $\begin{array}{l}\text { Higher run-off velocity, } \\
\text { destruction of habitats, } \\
\text { elimination of vegetation } \\
\text { structures, higher erosion of } \\
\text { river banks }\end{array}$ \\
\hline \multirow{2}{*}{$\begin{array}{l}\text { Drainage of } \\
\text { floodplain sites } \\
\text { ('land improvement') }\end{array}$} & $\begin{array}{l}\text { Until end of } 19^{\text {th }} \\
\text { century }\end{array}$ & Local & Low & \multirow{2}{*}{$\begin{array}{l}\text { Excavation of ditches, } \\
\text { transformation of vegetation, } \\
\text { increased surface run-off, } \\
\text { deepening of groundwater } \\
\text { table, reduction of natural } \\
\text { inundations }\end{array}$} \\
\hline & $\begin{array}{l}\text { End of } 19^{\text {th }} \\
\text { century }- \text { end of } \\
20^{\text {th }} \text { century }\end{array}$ & Widespread & High & \\
\hline
\end{tabular}

Tab 3. River regulation measures and land improvements, and their ecological impacts on the floodplains in the Gutland region.

However, it was not until the French regime that the main goal switched from flood protection to land improvement, as the military campaigns of the time demanded intensive agriculture. In 1796, the townships and residents were forced to clean up all water courses within a fixed time period and to build new bridges [I]. On $4^{\text {th }}$ May 1803, the first law on the 'Curage des canaux et rivières non navigables et l'entretien des digues correspondante' was enacted. 'Curage' (clean up) in this context meant deepening the river bed and the clearance of riparian vegetation [I]. Regionally, flood protection remained the top priority. In 1804, the townships of Moutford and Schuttrange applied for permission to deepen the bed of the River Syr and to excavate relief 
channels [I]. Although the scarce financial resources of the population permitted only local measures, the structural diversity of the streams was nevertheless degraded.

In the mid $19^{\text {th }}$ century, under the Belgian government, another motive for land improvement arose:

"Government interfered not primarily on agricultural grounds but for reasons of public health. Townships [...] and even villages on adjacent hills were haunted by remittent fever, because of the swamps fed by the water courses in the corresponding valleys." (Kohl, 1925)

Between 1830 and 1874, many ordinances and laws were enacted to drain swampy floodplains and to straighten water courses [I]. As the costs and execution were made the responsibility of the residents, the effect was only localised and the quality of the measures poor. The land improvements in the Bavarian fens produced similar outcomes (Beck, 1996). Between the years 1857 and 1874, 2,476 ha of meadowland were drained (Kohl, 1925). In 1874, the state assumed responsibility for the initiative and developed a concept for land improvement. This involved the foundation of a coordinating institution (the agricultural administration), the installation of the German engineer J. Enzweiler as coordinator, the allocation of subsidies, and a law on the implementation of syndicates for land improvement [V, VI]. The syndicates had the following tasks [VI]: (a) the cleaning, deepening and regulation of water courses, (b) the drainage of swampy meadows, (c) the installation of drainage and irrigation channels, and (d) the construction of field paths and land consolidation. Between the years 1881 and 1911, a $25 \mathrm{~km}$ stretch of water course was changed annually. A total water course length of $586 \mathrm{~km}$ (about 20\% of the total) was cleaned and regulated in Luxembourg between 1883 and 1919 (Frisch, 2003). Agricultural statistics revealed the drainage of 4,651 ha of meadowland between 1879 and 1889 [V].

After this push for land improvement the first negative aspects soon became obvious [VI]. Water runoff accelerated and provoked devastating floods; the deepening of the river beds limited the irrigation and natural inundation of the meadows; and the clearance of the margins of water courses was both aesthetically unattractive and threatened the survival of native aquatic species (see also table 3). In 1891, Lamort, the first critic of land improvement and river regulation in Luxembourg, also criticized the homogeneity of the measures implemented, which in his opinion did not respect the variable natural and geological settings of the Gutland [VI]. Commenting on the ecological impacts of the measures along the River Syr he stated:

"[...] the works serve to curb the reappearance of crabs in the Syr and also that of fish which cannot spawn in currents, those relying on sites now absent such as niches at the water's edge, root systems or protecting stones."

\subsection{The harnessing of water power}

Water was a very important resource for the creation of mechanical power up to the $19^{\text {th }}$ century and had certain impacts on the floodplain ecosystems (see table 4). Erpelding (1993) emphasised the rich variation in the different types of water mills in the Gutland. Essentially there were three categories, each with different impacts on the floodplains: (a) ship mills on navigable streams, (b) undershot mills along non-navigable streams and (c) overshot mills along any type of stream. Erpelding (1993) described the mills in the Gutland as follows:

"Often a long water channel led to the mill, sometimes bordered by willows and alders, dazzling like a silver belt within the meadow landscape." 


\begin{tabular}{|c|c|c|c|c|}
\hline INTERVENTION & PERIOD & SPATIAL INFLUENCE & INTENSITY & IMPACTS \\
\hline \multirow[t]{2}{*}{ Mill channels } & $\begin{array}{l}13^{\text {th }} \text { century - } \\
1850\end{array}$ & Widespread & High & \multirow{2}{*}{$\begin{array}{l}\text { Transformation of water } \\
\text { balance, reduced river } \\
\text { dynamics, destruction and } \\
\text { creation of habitats }\end{array}$} \\
\hline & $1850-1950$ & Local & Low & \\
\hline \multirow[t]{2}{*}{ Relief channels } & $\begin{array}{l}18^{\text {th }} \text { century - } \\
1850\end{array}$ & Local & High & \multirow{2}{*}{$\begin{array}{l}\text { Transformation of water } \\
\text { balance, Higher run-off } \\
\text { velocity, reduced river } \\
\text { dynamics, destruction and } \\
\text { creation of habitats, lower } \\
\text { flood risk locally }\end{array}$} \\
\hline & $1850-1950$ & Local & Intermediate & \\
\hline \multirow[t]{2}{*}{ Installation of weirs } & $\begin{array}{l}13^{\text {th }} \text { century - } \\
1850\end{array}$ & Widespread & High & \multirow{2}{*}{$\begin{array}{l}\text { Lower run-off velocity and stil } \\
\text { waters, sedimentation, } \\
\text { transformation of water } \\
\text { balance, rise of groundwater } \\
\text { table, higher water retention } \\
\text { locally, creation of habitats }\end{array}$} \\
\hline & $1850-1950$ & Local & Low & \\
\hline Lifting of river bed & $\begin{array}{l}13^{\text {th }} \text { century - } \\
1850\end{array}$ & Widespread & High & $\begin{array}{l}\text { Steeper incline, increased } \\
\text { river dynamics, higher flood } \\
\text { risk, elimination of vegetation } \\
\text { structures }\end{array}$ \\
\hline
\end{tabular}

Tab 4. Mills and their ecological impacts on floodplains in the Gutland region.

Water mills have been known in Western and Central Europe since the $5^{\text {th }}$ and $6^{\text {th }}$ centuries, with thousands of mills inhabiting the landscape during Carolingian times in the $8^{\text {th }}$ and $9^{\text {th }}$ centuries (Haslam, 1991, Konold, 2005). However, the first documented mills in the Gutland date from the late Middle Ages and were located in the Syr Valley. In 1200, there were two mills in Schuttrange and in 1321 there was one in Syren (Trossen, 1997). From the Middle Ages there were 22 mills - mostly flour mills - operating in the Syr Valley alone (Erpelding, 1991). Agricultural statistics specify the types and the development of mills in Luxembourg [V]. In the first half of the $19^{\text {th }}$ century, oil mills, often combined with flour mills, were prevalent up until the point at which water power was replaced by steam power. In 1862, there were 102 oil mills in Luxembourg however by 1889 only 17 were left. There were 49 sawmills in 1862 declining to only 10 in 1889. Several other industries also used water power in 1889, including 10 tan bark mills, 7 gypsum mills, 2 clover mills and 3 roller mills, among others [V]. Iron, paper and chinaware factories also harnessed the power of the Gutland streams.

\subsection{Navigation and timber floating}

The history of navigation in Europe is a very old one, dating back to Etruscan and Roman times when the first canalisation works along the Mosel opened a passage from the Saône to the North Sea in 58 AD (Haslam, 1991). In the Gutland, medieval improvements after the postRoman decay were linked mainly to the large rivers, the Mosel and the Sauer. In the $12^{\text {th }}$ century, the Echternach Abbey allowed boats to sail the Sauer and implemented the necessary river regulation works. Fleets of boats owned by the cities and the nobility of the region have been documented since the Middle Ages (Hamer, 1958). The impacts of navigation activities up until the $19^{\text {th }}$ century can be summarised as follows: a deepening of river beds, consolidation of river banks, elimination of meanders, cutting off of side arms and the cessation of fishing [III]. However, there were also direct impacts on the adjacent floodplains resulting from man-and horse-towed boats, a technique also frequently used in $18^{\text {th }}$ century Britain (Haslam, 1991). An ordinance passed by the French government for Luxembourg in 1805 stipulated the maintenance of an open corridor 24 feet wide along either side of the river to allow the passage of horse-drawn boats, including the clearance of trees (Konsbruck, 1970). At this time, $58 \mathrm{~km}$ of the River Sauer were navigable. After several plans for ambitious channel projects the Mosel was finally canalised in 1956 [III]. The floating of round timber temporarily enjoyed greater importance than navigation on big rivers in forested areas, such as the Mosel and the Sauer [I]. The rafting of logs remained common along smaller water courses, however 
this had repercussions for the floodplains due to the generation of artificial backwaters and floods to raft the wood.

\subsection{Mining activities}

Since Roman times, substrates such as sand and gravel have been removed from rivers with wide gravel beds like the Rhône, Rhine and the large Italian rivers (Haslam, 1991). Similar excavations for the construction of roads and buildings have also been documented for Gutland streams (Hamer, 1958). The exploitation of these materials altered the river ecosystems by deepening the riverbeds and completely transforming the sole and riverbank structure. In contrast to the south of Luxembourg - where bog ore was abundant - mineral extraction had relatively little direct impact in the Gutland, however the leaching of heavy metals from the mining sites in the south has had drastic effects on the floodplains of the River Alzette. The Mosel and Sauer rivers suffered additionally from the commercial extraction of shell limestone for building and agricultural purposes (Gonner, 1876).

\subsection{Fisheries}

In the Gutland, commercial fishing was a privilege of the nobility and the clergy (Van Werveke, 1983). Water courses were retained with earth walls or brick works, and fish were caught with flues or bow nets. The origins of fish farming using artificial ponds dates back to the $13^{\text {th }}$ century in southern Germany and Switzerland, with its zenith in the $14^{\text {th }}$ century, arising from a high demand for fish as a luxury commodity (Schnitter, 1992, Konold, 2005). Fishing ponds were established mainly on marshy sites not suitable for agriculture, but also on more productive sites as the demand and the prices paid for fish increased (Schnitter, 1992). These artificial constructions dominated the landscape until the end of the $19^{\text {th }}$ century when the importance of fisheries declined (Gonner, 1876, Van Werveke, 1983). The story of fisheries in the $20^{\text {th }}$ century has been one of loss: salmon and many other fish species disappeared as a consequence of overfishing, waterway obstruction and pollution. The beaver was also systematically exterminated as it was considered a 'pest' and its considerable role in moulding the landscape was deemed undesirable (Letzeburger Sportfescher, 1955).

\section{Land use change in the Syr Valley: the Schlammwiss-Aalbach}

\subsection{Situation in 1777 (Austrian period and agrarian movement)}

Rapid population growth in Western and Central Europe (numbers doubled between 1740 and 1805 ) and the growing demand for food, provoked a considerable upsurge in wheat prices, even as the wages paid to day labourers and workers declined (Abel, 1978). The effect of this was the promotion of agriculture and the initiation of land improvement projects in Central Europe so as to increase the area under cultivation and cereal yields.

However, at this point in time the floodplain of the study site was characterised by largely intact river dynamics and extensive land use. Ferraris' map shows that the floodplain was largely deforested and the course of the Syr was clearly evident in the valley bottom [II] (see figure 2). The meanders plotted on the map were presumably highly variable, altering with flood pulses. Almost no corrections to the course of the river had yet taken place, with the exception of a small straightened stretch immediately before the Mensdorf village. This first regulation served two flour mills located in the village [V]. The land adjacent to this regulated stretch of the Syr was revealed on the map as cultivated land [II]. This was the first part of the floodplain drained as a consequence of the small corrective measure, probably designed to provide more arable land in the vicinity of the village.

The bed of the River Syr was an average of 14 feet wide and 5 feet deep, with a stony structure and steep river banks [II]. The land use in the floodplain was described uniformly as marshy grassland (prairies marécageuse) [II]. Occasional flood events were reported [II]. It is likely, therefore, that the site characteristics varied in terms of wetness and land use. The land register from the time of Maria Theresia specified the land use distribution in the Syr Valley as $80 \%$ cultivated land and $12 \%$ grassland, with the grasslands corresponding to the floodplain areas [IV]. Erpelding (1991) found a note on the productivity of the meadows belonging to the miller 
from Mensdorf in the land registers from 1766. It stated that a two cut system for haymaking was applied, and that productivity was quite low, suggesting that grazing practices and poor site conditions affected production.

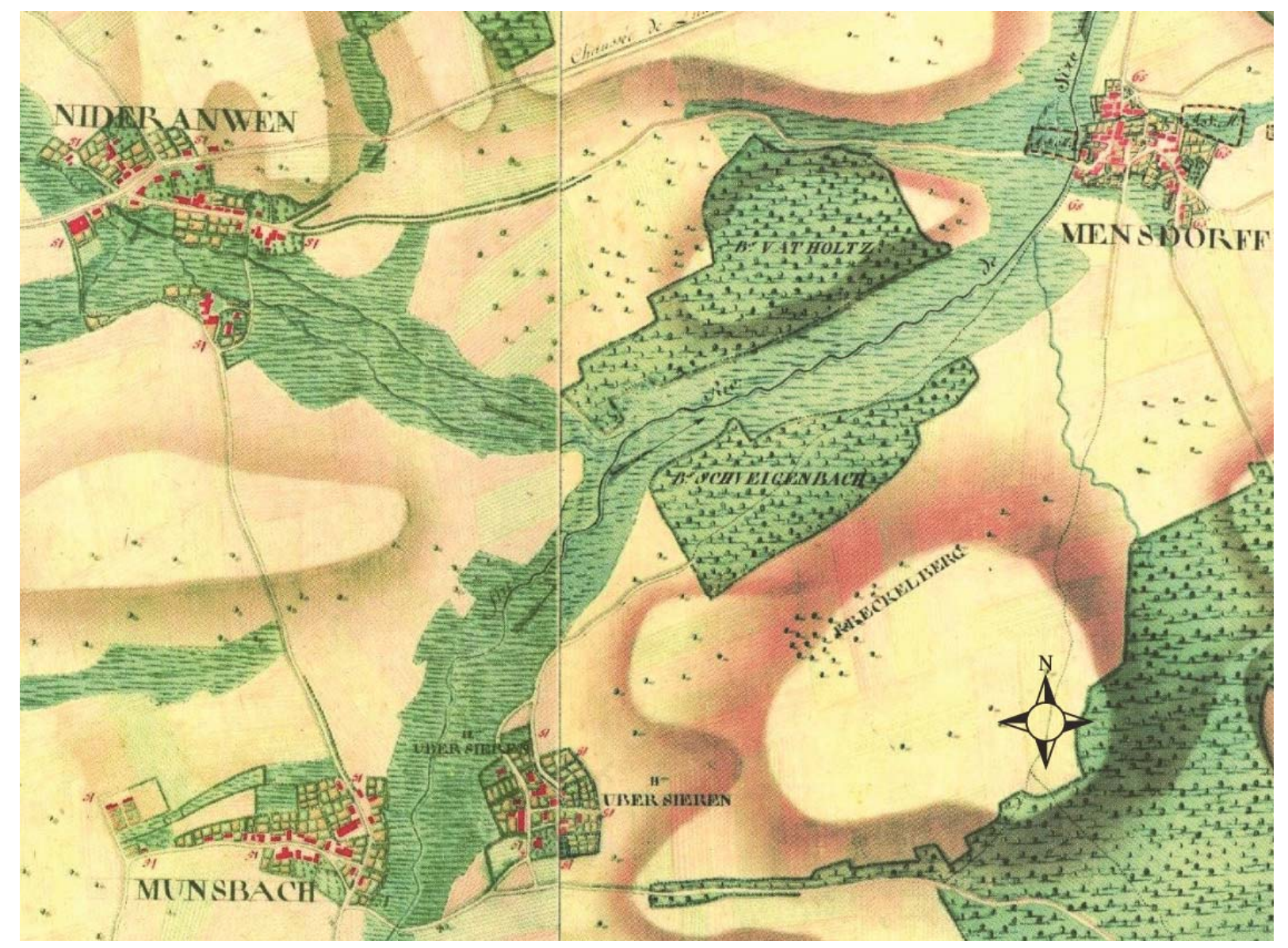

Fig 2. Excerpt of the 'Schlammwiss-Aalbach' study site (Syr Valley) from Carte de Cabinet des Pays-Bas Autrichiens du général Joseph de Ferraris of 1777, scale 1/11.520 (with friendly permission of Bibliothèque royale de Belgique, Brussels).

\subsection{Situation in 1830 (Dutch period, agrarian boom and first crisis)}

The high demand for food forced price rises for both agricultural produce and land in Europe. Subsequent strong harvests between 1819 and 1825 resulted in a deterioration in cereal prices, with many landlords becoming indebted and halting land improvement measures (Abel, 1978). The effects of this general agri-economic development were also evident in the Syr Valley and the people of Luxembourg also suffered high taxes under both French and Dutch rule as well as a decaying infrastructure and isolation from European trade (Schmithüsen, 1940).

The first local clearances and regulation measures along the River Syr between 1777 and 1830 were mainly initiated to run the mill in Mensdorf and to improve grasslands [IV]. The administrative acts revealed two instances in the case of the Schuttrange township. In 1804, a request was made for permission to construct two drainage channels and in 1810 the Syr was 'cleaned up' [I]. Land register maps of the study area also revealed a completely different course of the Syr in comparison to that marked on Ferraris' map [II, IV] (see figure 3). Corrective measures must have taken place during the French regime at the beginning of the $19^{\text {th }}$ century, trapping the Syr in a canalised bed along the edge of the valley. The course of the old River Syr along the valley floor is still visible owing to the irregular parcel boundaries [IV] (see figure 3 ). 


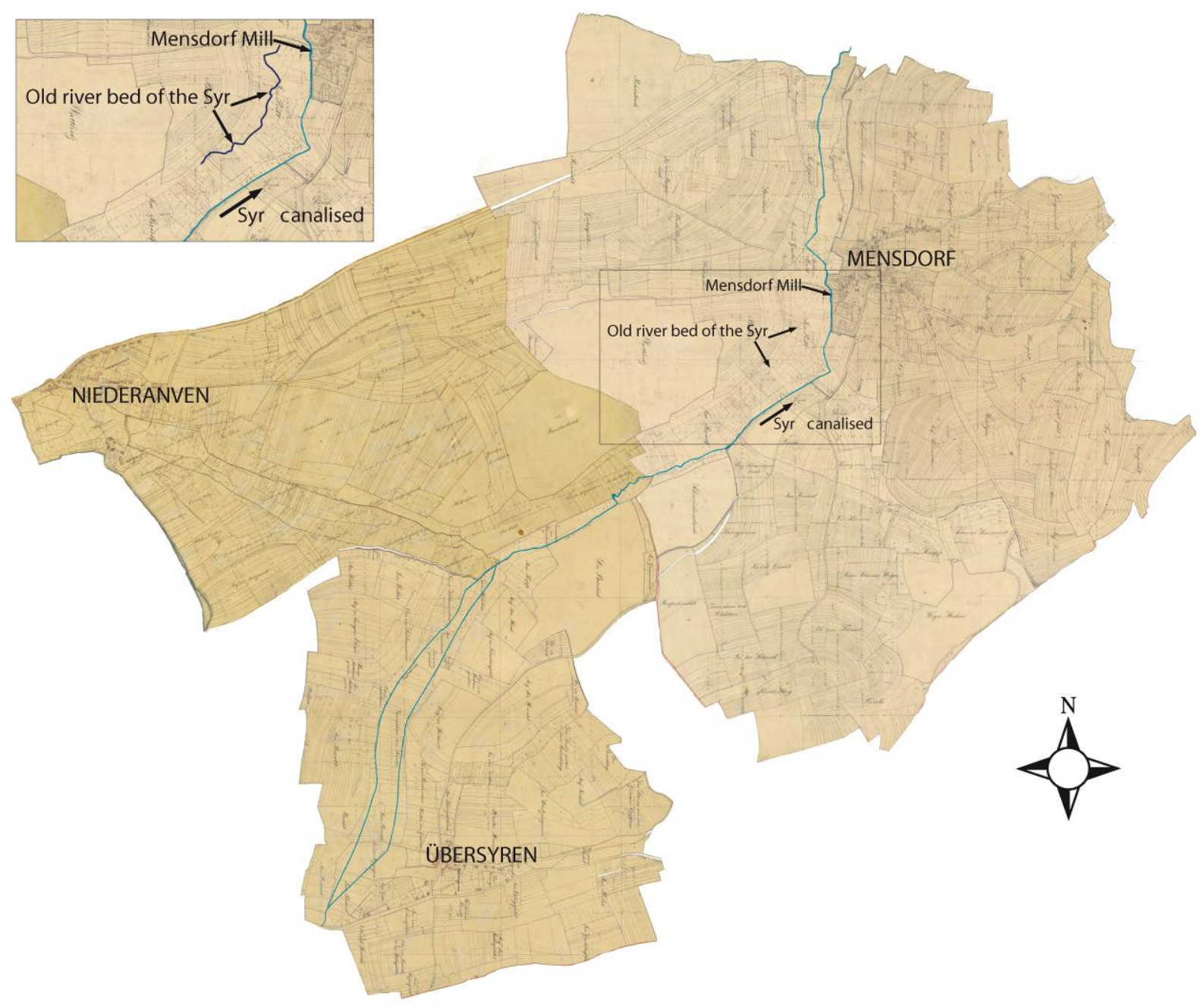

Fig 3. Excerpt of part of the 'Schlammwiss-Aalbach' (Syr Valley) study site from the land register map of the Betzdorf township from 1830, scale 1/2.500 (@ Administration du cadastre et de la topographie Luxembourg, excerpt of primal land register from 1830, permission from $19^{\text {th }}$ April 2007).

Further information in relation to land use was extracted from a petition made by a Mensdorf miller in 1829, which contained construction plans for a second mill wheel [I, III]. No further release or drainage channels were installed, tree rows were planted along parts of the Syr, and the main type of land use in the floodplain was grassland. In 1857, this mill became the subject of a legal action when the local residents held the mill responsible for flooding in the floodplain [1]. The miller was subsequently forced to build a release channel and to clear the dams periodically [I].

\subsection{Development from 1839 to 1891 (autonomy, industrialisation and agrarian crisis)}

After the short crisis, agricultural prices recovered with a decline in wages, the costs of production and taxes, in combination with an even more rapidly growing population in the $19^{\text {th }}$ century (Abel, 1978). New cultivation techniques and crops, and the division of common land served to raise agricultural productivity (Tracy, 1989). However, bad harvests and massive grain imports from overseas reduced prices in Europe and led to the agricultural crisis of 1880. The entry into the German tariff union in 1842 and the systematic extension of infrastructure since that time paved the way for the intensification of Luxembourgian agriculture and European trade (Schmithüsen, 1940).

An increasing number of infrastructural works also altered the Syr floodplain, and the period heralded a first land improvement offensive designed to raise agricultural production to cater for the growing population. In 1861, a railway connection between Luxembourg City and Germany was established on an earthen bank. The railway line passed through the study site, reducing the floodplain area and changing the hydrological system severely [III, IV]. 


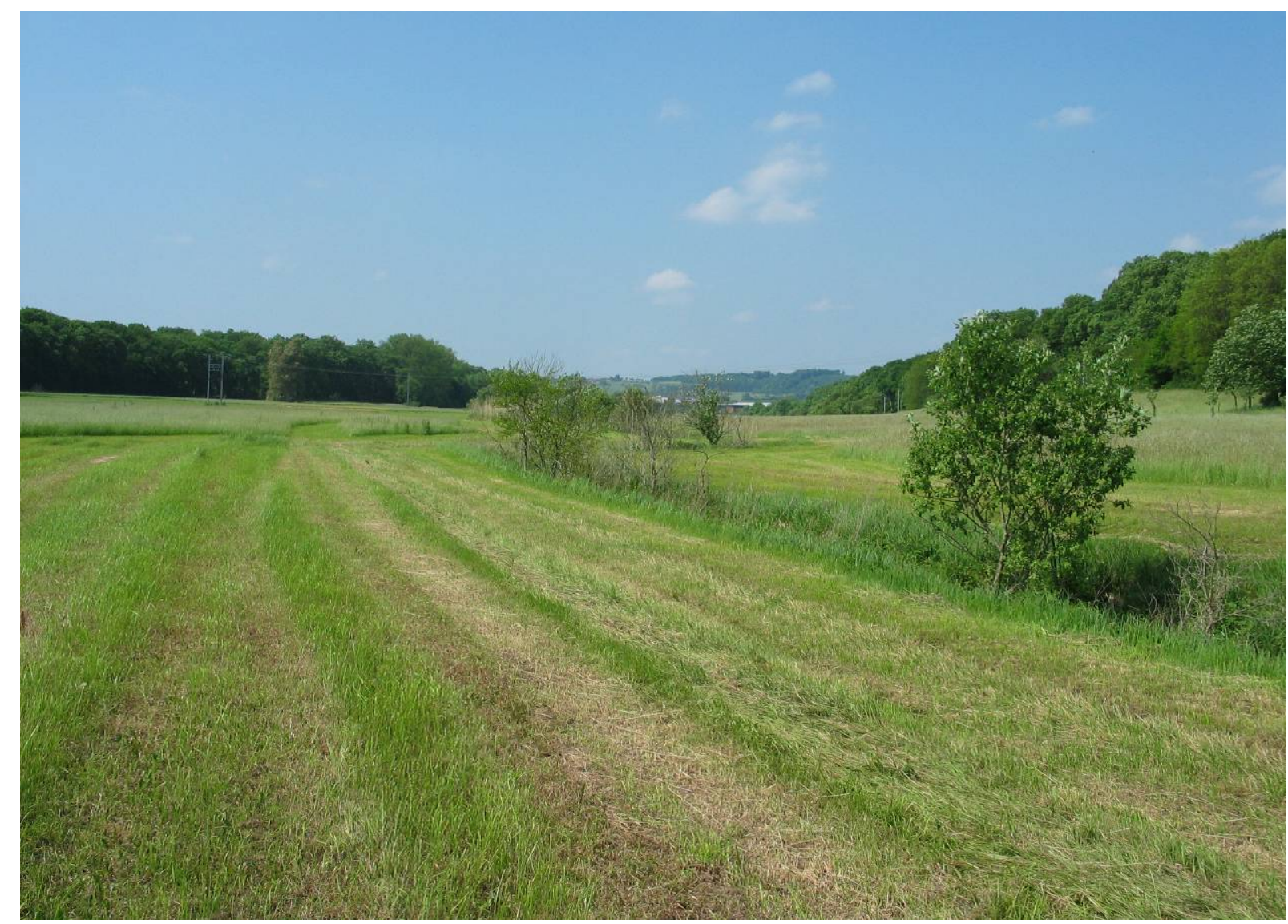

Fig 4. Drainage ditch and mown grasslands in the valley flat of the Syr floodplain in 2003 (picture: C. Paulus).

After its foundation in 1883, the Agricultural Administration initiated systematic land improvement schemes in the Syr floodplain [VI, VII]. The River Syr was regulated, and the water course length between the villages Moutfort and Wecker was reduced from 19,936 m to 19,017 $\mathrm{m}$ [VII]. The reduction of the water course length within the area of the study site at this time was only $16 \mathrm{~m}$ due to earlier regulation measures carried out under the Dutch government [VII]. The regulation measures increased the stream velocity of the river. Additionally, the profile of the 'new' Syr was widened to absorb more water in the event of flooding and the bordering vegetation was removed, including the root systems [VI]. The land was systematically drained by excavating 2,500 $\mathrm{m}$ of ditches in Schuttrange in 1886 and 2,100 $\mathrm{m}$ around Mensdorf between 1883 and 1891 [VI, VII] (see figure 4). After the crisis of 1880, the prices for livestock products increased in comparison to vegetable and cereal produce, thus the improvement of grasslands remained profitable. The engineer responsible, J. Enzweiler, stated that countless ditches already existed in 1883, installed by land managers. However, it was not until the systematic land improvements began that there were considerable effects on land use in the study area:

"The meadows between Roodt and Mensdorf have been considerably improved by the regulation, the marshy sites have disappeared and today bear nutritious and abundant forage. Between Mensdorf and the boundary of Niederanven the results of the drainage measures in the last year will be significantly enhanced." [VI]

\subsection{Development from 1891 to 1945 (neutrality, the world wars and agrarian protectionism)}

Up until 1896, the repercussions of the agrarian crisis and the general economic depression further aggravated the problems facing European agriculture. Even so, the decline in the prices for livestock products was never as great as in the case of grain. The best policy for European countries to adopt during the great depression, therefore, was to shift from crop to livestock production (Tracy, 1989). As a response to the depression, many European countries also 
adopted a policy of protectionism in agriculture, placing tariffs and duties on agricultural produce. As a member of the German tariff union, Luxembourg profited from stable prices and markets. In 1922, Luxembourg and Belgium formed an economic union with a tariff system. Under this union, agriculture in Luxemburg received extra payments to compensate for lower market prices. Livestock production became even more important, accounting for $72 \%$ of the total agricultural production in 1934 (Schmithüsen, 1940). This resulted in a considerable increase of grassland cover (e.g. 25\% in the Canton of Luxembourg from 1913 to 1937) and further pressure to improve floodplain wetlands. This pressure increased during the occupation by Nazi Germany and the subsequent introduction of a planned economy in agriculture (Schmithüsen, 1940).

In the Schlammwiss-Aalbach area, the period of autonomy and protectionism was characterised by a downturn in the number of new land improvement measures and an increased emphasis on the maintenance and effectiveness of the existing infrastructure. Documents pertaining to land improvement reported a cleanup in 1911 of the major drainage ditch lengths of between 635 and $1,420 \mathrm{~m}$ by communal land improvement syndicates [VII]. The documents defined the cleanup process ('curage') as the clearance of all vegetation and the dredging of sediments in the ditches [VII]. Problems arising as a consequence of the regulation of the River Syr became increasingly apparent:

"In places the river bed is filled with mud up to the rims of the river banks, so that after the lightest of rainfalls water inundates the valley meadows." [VII]

The bed of the River Syr was subsequently cleaned along its entire length in 1931, and in 1937 the last meandering stretch of the Syr, at the township border between Betzdorf and Niederanven, was regulated at the initiative of the Agricultural Administration [IV, VII]. The old riverbed was filled in with excavated soil. The bed of the River Syr was $4 \mathrm{~m}$ wide and followed a constant incline of $1 \%$ [III].
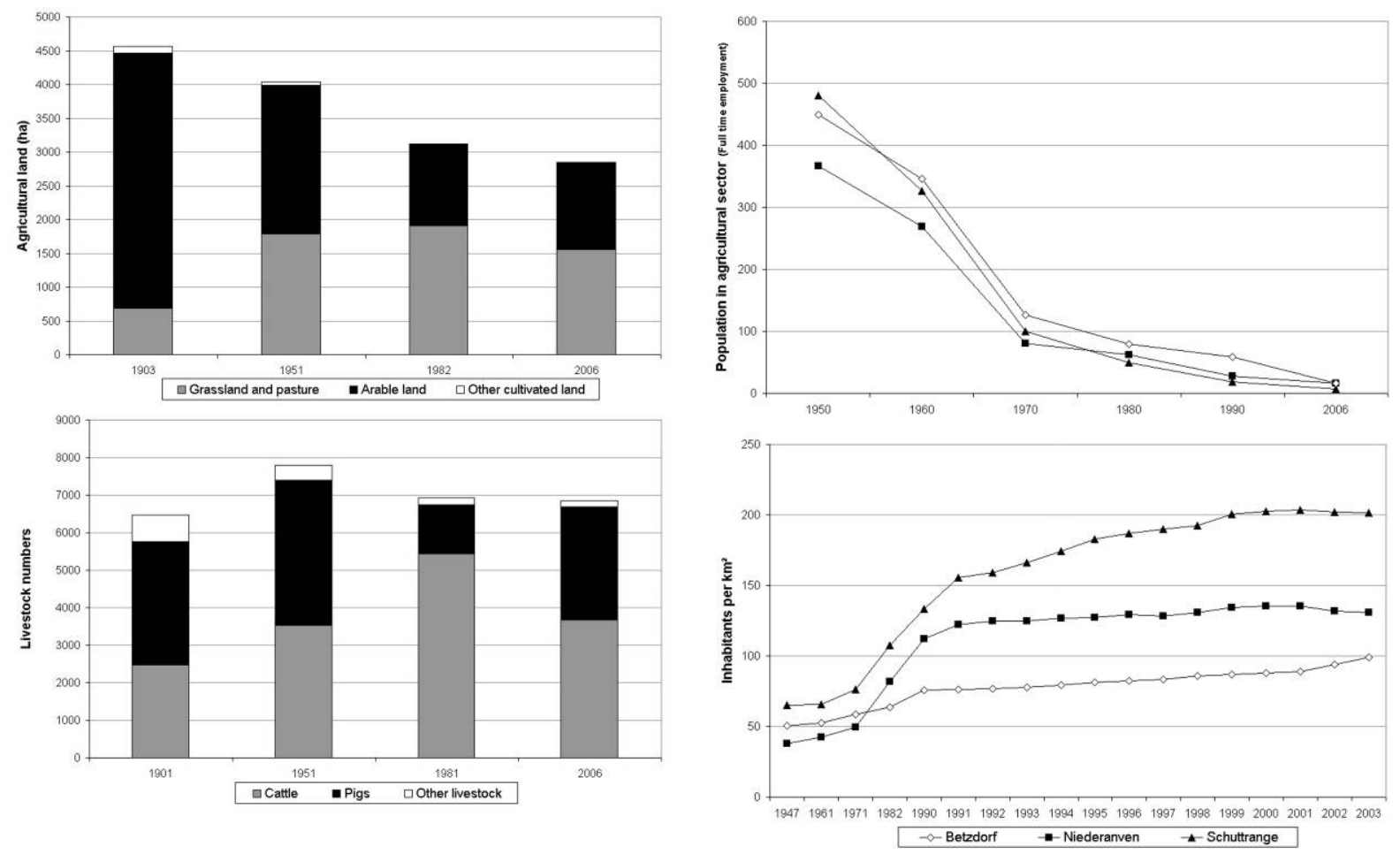

Fig 5. Development of agricultural lands and livestock numbers in the three townships Betzdorf, Niederanven and Schuttrange.

Fig 6. Development of population active in agricultural sector and population density in the three townships Betzdorf, Niederanven and Schuttrange. 
To prevent further flooding events arising after the construction of the mill weir in Mensdorf, a new relief channel was constructed [IV, VII]. None of the aforementioned measures served to drain the meadows in the study area completely [VII]. This fact was also documented in an agricultural report drafted by the Reichsnährstand in 1941, during the German occupation [VIII]. The occupying German force ordered the Luxembourgian administration to drain 100 ha of the Syr floodplains in the study area but the project was never carried out. Land use descriptions stated that two-thirds of the land around Mensdorf was cultivated and one-third was grassland [VIII]. The Syr floodplain consisted solely of grassland and was used mostly as permanent pasture with paddocks and partly as combined meadow-pasture [VIII]. The increase in the importance of livestock production and the subsequent growth in the relative importance of grasslands in the three townships are documented in figure 5.

\subsection{Development from 1945 to 2000 (autonomy, industrial agriculture and peri urbanisation)}

The major post-war concern throughout Europe was to raise agricultural production in order to meet the growing food shortages. Most western European countries provided incomes or price guarantees to their farmers. Moreover, the technological revolution in agriculture brought about increased labour productivity and higher outputs. Thus, a further intensification of production occurred without adaptation to the changed markets (Tracy, 1989). In 1948, Luxembourg became a member of the Benelux customs union. Again agriculture in Luxembourg was granted special assistance in the form of additional payments and higher guaranteed prices paid to farmers (Tracy, 1989). When the Common Agricultural Policy was adopted by the European Economic Community in 1960, Luxembourg was still mainly rural in character (see figure 6), with urbanisation processes just about to start around the capital.

\begin{tabular}{|c|c|c|c|}
\hline YEAR & VILLAGE & TOWNSHIP BOUNDARY & MEASURE \\
\hline 1911 & $\begin{array}{l}\text { Between Mensdorf and } \\
\text { Roodt-Syre }\end{array}$ & Betzdorf & $\begin{array}{l}\text { Sludge and vegetation removal from } \\
\text { drainage ditches }\end{array}$ \\
\hline 1931 & $\begin{array}{l}\text { Between Mensdorf and } \\
\text { Übersyren }\end{array}$ & Betzdorf, Schuttrange & Straightening and clean-up of Syr river bed \\
\hline 1932 & Übersyren & Schuttrange & $\begin{array}{l}\text { Clean-up and sludge removal of Syr river } \\
\text { bed }\end{array}$ \\
\hline 1937 & Übersyren & Schuttrange & $\begin{array}{l}\text { Clean-up and sludge removal of Syr river } \\
\text { bed }\end{array}$ \\
\hline 1939 & Mensdorf & Betzdorf & $\begin{array}{l}\text { Clean-up and sludge removal of Syr river } \\
\text { bed }\end{array}$ \\
\hline 1941 & Mensdorf & Betzdorf & Drainage of meadows and cultivated land \\
\hline 1946 & Mensdorf & Betzdorf, Niederanven & Drainage of floodplain area "Im Brill" \\
\hline 1947 & Mensdorf & Betzdorf & Drainage of floodplain area "Im Ritt" \\
\hline 1958 & Mensdorf & Betzdorf, Niederanven & $\begin{array}{l}\text { Sludge and vegetation removal from } \\
\text { drainage ditches "Im Brill" and "Niederbant" }\end{array}$ \\
\hline 1958 & Mensdorf & Betzdorf, Schuttrange & $\begin{array}{l}\text { Drainage of floodplain area "In der } \\
\text { Schlammwiss" }\end{array}$ \\
\hline 1960 & Münsbach & Schuttrange & $\begin{array}{l}\text { Drainage of floodplain area "In den } \\
\text { Azingen" }\end{array}$ \\
\hline 1983 & Mensdorf & Betzdorf & $\begin{array}{l}\text { Drainage of floodplain area "Deich, } \\
\text { Sauerwies, Vor Kiemes" to create land for } \\
\text { construction }\end{array}$ \\
\hline 1987 & Münsbach & Schuttrange & $\begin{array}{l}\text { Drainage of floodplain area to build } \\
\text { motorway bridge }\end{array}$ \\
\hline
\end{tabular}

Tab 5. Land improvement and river regulation measures in the local study area, Schlammwiss-Aalbach, between 1911 and 1987 [VII, IX]. 
Drainage activities were intensified after the Second World War with the foundation of various land improvement syndicates, and land use changed considerably as a result. The purpose of the syndicates was to develop a drainage system for the entire Syr floodplain, and to use tractors to mow the dried grasslands [VII, IX]. Table 5 indicates that the measures implemented up until 1945 consisted mainly of river regulation, whereas after 1945 there was a greater emphasis on drainage and the maintenance of the corrections made to the river's course. The elimination of the mill dam brought about an increase in the stream velocity and greater erosion of the channelled river bed [VII]. As a consequence of the alterations, the marshy character of the grassland during the vegetation period was lost and land use in the floodplain became increasingly homogeneous [VII, IX]. Until the 1970s, almost the whole area was used as hay meadow-pasture managed in a two cut regime [IX]. Cattle grazed the stubble in the meadows following the second cut in September [IX]. Common grazing in the floodplains was phased out in the 1980s and some of the meadows were converted back to paddock pastures [IX]. The result of the measures undertaken in this period was the creation of a more uniform floodplain in terms of vegetation structures and site characteristics.

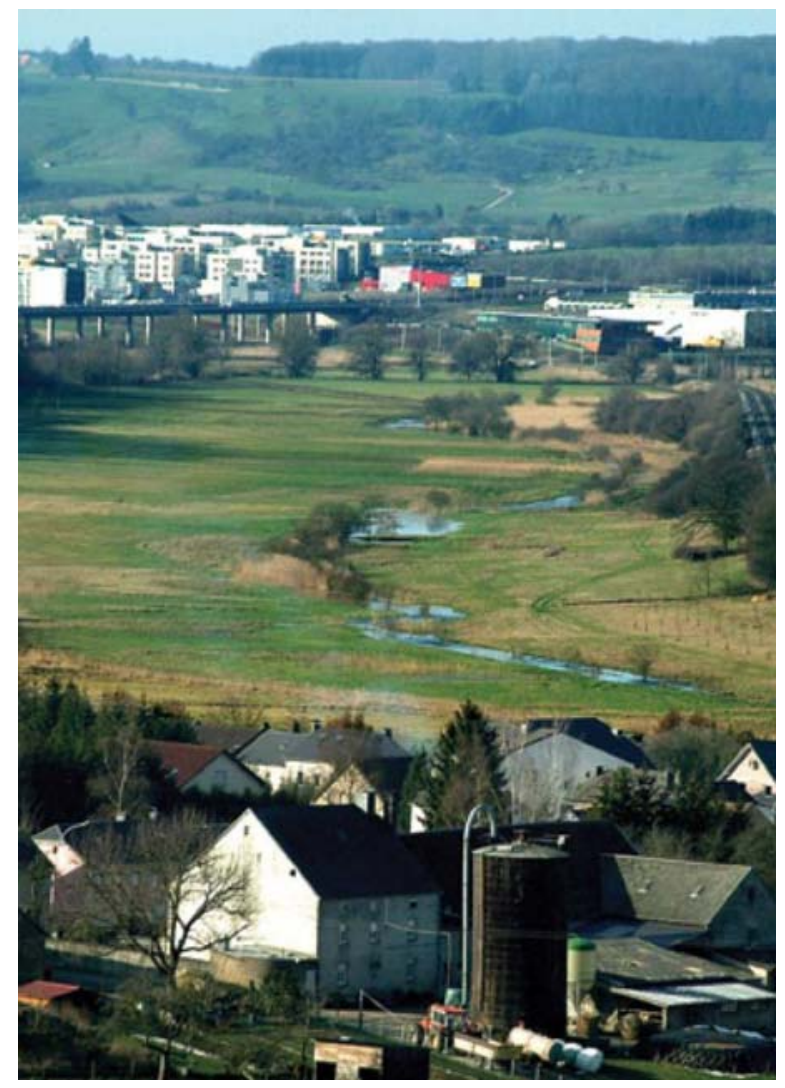

Fig 7. Aerial view of the peri-urban Schlammwiss-Aalbach area (Syr Valley) in winter 2003/2004. (Mensdorf village in the forefront; new industrial areas and the train track on the right side; and in the back, the highway bridge crossing the area) (picture: Administration de la Nature et des Forêts, Luxembourg).

\section{Implications for landscape management and restoration}

\subsection{Local land use histories for landscape planning}

In the vicinity of the urban centre of Luxembourg City, the weight of human impacts has varied considerably over time and the rural floodplain landscapes were not altered in a gradual manner. To the contrary, the modification occurred in several temporal phases, with increasing intensity in the last century. The area has been altered: from a place of resource extraction and livestock herding up until the beginning of the $18^{\text {th }}$ century, to a principal energy provider and transport route up until the time of the French Revolution; from a fertile ground for agricultural production in the $19^{\text {th }}$ century, to finally a host to infrastructural facilities, residential areas, waste disposal sites, and recreational and conservation areas. Such local land use histories can assist landscape planning in the peri-urban context in many ways. 
Firstly, the local land use history provides an accurate description of the origins of landscape elements and land use systems, their functioning, and repercussions for landscape integrity (Marcucci, 2000). This is important, because the effects of certain land use periods on matter fluxes and landscape functionality may in some cases arise only after a time lag and with significant local variations, which general histories often fail to reveal. The drainage and river regulation measures of the $19^{\text {th }}$ century were intended to create dry grasslands across the floodplains of the Gutland. The local focus on Schlammwiss-Aalbach revealed, however, that although the aforementioned measures changed the riverbed structures, only a few floodplain sections in this part of the Syr Valley lost their wet and marshy site conditions completely. There was, in fact, no major change of site conditions evident in this area until the Mensdorf mill was dismantled in the $20^{\text {th }}$ century.

Secondly, local historical research serves to identify the most valuable historical elements and predominant historical land uses in floodplains, which should be protected or should be restored. We identified the sites of many mills and their canals in the valleys of the Gutland, which qualify as features of local heritage. The focus on the local case study also revealed livestock herding as the main land use until the first half of the $20^{\text {th }}$ century as well as the almost unchanged general landscape structure since the $18^{\text {th }}$ century, described as an open grassland floodplain. This finding is also valid for many other floodplain landscapes in Europe (Large \& Petts, 1996, Konold, 2005). However, a study of rural mountainous floodplain landscapes in France revealed the contrary finding that floodplain forests - following deforestation in previous centuries - have again expanded since 1920 due to watershed reforestations and the abandonment of pastoral activities (Piégay \& Salvador, 1997).

Lastly, our findings have brought potential sites for restoration, either with a relatively continuous habitat tradition or which have been heavily deteriorated, to the attention of policy makers, administration and the general public. As a consequence, the likelihood that planning processes will seek to enhance the ecological functioning of the severely impacted Gutland floodplains has increased. For Large and Petts (1996) the survey of the historical river development is also a very important component of restoration planning and helps to identify suitable sites as starting points for restoration. The historic research can also serve to promote public interest in landscape planning and its concepts by involving long-term residents, citizens' organisations and communities (Höchtl et al., 2007) and can be a starting point for a participatory planning process (Jessel \& Jacobs, 2005).

\subsection{Floodplain management in peri-urban landscapes}

While the principle lines of land use history are similar to many floodplain landscapes in Western and Central Europe, the velocity of the conversion of the Gutland and especially the Syr Valley from rural to peri-urban landscapes starting in the late 1970s was unprecedented. In the process of peri-urbanisation, through which the landscapes affected become complex and intensively used spaces (Antrop, 2004), the challenge for the managers of new floodplain landscapes will be to generate ecological as well as cultural sustainability. Cultural sustainability means that landscapes that evoke people's enjoyment and approval are more likely to be sustained and cared for by humans over the long term (Nassauer, 1997). In a period of rapid change and where there are many external pressures, specific historic values and newly restored functions can be most efficiently initiated and protected through a participatory landscape planning process (Renes, 2004). The task will be to define landscape development goals for certain floodplain sections, also taking into account local residents' perceptions of landscapes and development measures (Schaich, 2009), and to build coalitions with relevant stakeholder groups to lead landscape development in line with the stipulations of the European Water Framework Directive (WFD) (Rohde et al., 2006). From his analysis of floodplain development policy in the UK, Parker (1995) also concluded that floodplain planning decisions should take greater account of the natural and cultural functions of floodplains.

The creation of ecologically sustainable floodplains in the Gutland valleys requires the restoration of river-water dynamics and connectivity between floodplain sections and, at the same time, the conservation of certain habitat traditions. Restoration could concentrate on the most severely impacted sites through river regulation measures, but also on sites - as in 
the Schlammwiss-Aalbach case - where the restoration goals correspond with habitat traditions. Restored floodplain sections can provide indispensable ecosystem services in periurban landscapes, such as flood control, the retention of pollutants and nutrients, the provision of water resources - the Gutland is experiencing falling groundwater levels - and biodiversity conservation. In times of climate change such areas also provide 'new' functions such as the sequestration of carbon dioxide and the buffering of extreme peaks of flood events.

For the conservation of traditional landscape elements it is vital to keep the local landscape knowledge of the population alive and to attribute new and socio-economically viable functions to such elements (Konold, 1998, Mata Olmo \& Muñoz, 2004). These landscape elements comprise valleys with artificial ponds or functional mill entities, and areas where the intervention into the hydrology of the landscape served to create new wetlands and inland water systems (Konold, 2007). The Luxembourgian Administration's programme for visitors' centres in valuable ecosystems should be used for the rehabilitation of historical buildings in the Gutland and the implementation of environmental and historical educational programmes on river landscapes. Greater accessibility to the floodplains would facilitate the local population's and visitors' ability to experience the ecological values and cultural relics of riparian landscapes, however, this should be carefully designed and restricted in ecologically valuable areas such as breeding bird habitats.

The historical perspective can also provide ideas for future land use options and alternative landscapes (Marcucci, 2000). The Schlammwiss-Aalbach case study revealed the almost unchanged landscape structure since the $18^{\text {th }}$ century and the importance of livestock herding for the grassland ecosystems. Therefore the reintroduction of the common grazing tradition in parts of the Gutland floodplains with modern low-intensity grazing systems or the reestablishment of trees along mill channels could be used to create 'new' cultural landscapes, which tie into the historic land use traditions (Schaich et al., 2010). The possibilities for the establishment of 'new' land uses of this kind are growing as farmers in the region begin to realise the potentials associated with the diversification of landscape management and the benefits of rural recreation and marketing. This move away from purely agrarian production to regional development, supported by national and European agri-environmental programmes, offers new possibilities for building coalitions with nature conservationists and water administration authorities for the development of ecologically and culturally sustainable floodplain landscapes.

\subsection{Restoration objectives in peri-urban landscapes}

In the case of cultural landscapes in peri-urban floodplains where restoration is targeted, the potential natural vegetation should be only one of many guidelines adhered to. Riparian forests, the potential natural landscape elements, are virtually absent from the Gutland. As ecological restoration should be process-oriented, the floodplain mosaic could also provide options for these elements, at least as riparian buffer corridors (Decamps et al., 2004). However, the development of natural processes to a full extent requires large expanses, which are frequently unavailable in peri-urban landscapes. Moreover, anthropogenic habitats such as the wet floodplain grasslands are identified as the traditional floodplain landscape elements in the valleys of the Gutland and host a large part of Luxembourgs's biodiversity. Large and Petts (1996) conclude similarly for their study of the historical development of River Trent that the restoration of a pristine river is inconceivable for the majority of rivers in the UK and Europe.

In this sense, Hampicke and Roth (2000) argued that one of the best contributions of Central Europe to the Convention of Biological Diversity (CBD) will be the re-establishment or mimicry of such traditional landscape structures and land uses. The Schlammwiss-Aalbach site has the potential to support semi-open wet grasslands and protected bird species within the Natura 2000 network. In this case, function, biodiversity, and habitat continuity represent more appropriate guiding objectives for restoration than the potential natural vegetation. Such restoration objectives are especially important in peri-urban environments as peri-urbanisation often generates very anthropogenic open spaces such as parks, gardens, and intensively used agricultural land (Haase \& Nuissl, 2007). The historic biotope conditions in SchlammwissAalbach revealed a habitat tradition of open and semi-open wet grasslands dating back to 
the mid $20^{\text {th }}$ century. Grassland management based on low-intensity cutting and grazing practices also remained largely unchanged until this epoch. Following the restoration objectives of ecosystem functionality and biodiversity, restoration measures in Schlammwiss-Aalbach might, therefore, recreate hydrological functionality, reinforce river dynamics and implement a modern functional and self-sustaining management complex through mowing and/or lowintensity grazing to maintain the traditional semi-open landscape character.

\section{Conclusions}

The history of the Gutland floodplains can be summarised as a relatively slow change from a semi-natural to a semi-managed landscape followed by a quite rapid change from a semimanaged to a peri-urban landscape. However, the detailed investigation of the history of human interventions at the regional and local level revealed that the impact of land use changes can vary considerably between floodplain sections and habitat traditions may be very persistent. A preferable starting point for landscape planning would be the determination of development goals for floodplain sections according to a gradient of human intervention and specified landscape impacts, based on local land use histories.

In the highly complex land use history of peri-urban floodplain sites, where river regulation measures have often counteracted each other or created new ecological values, planning should be better integrated with habitat traditions through the use of functionality and biodiversity as restoration guidelines. Here past land uses may serve as archetypes for sustainable modern peri-urban schemes. The development of ecologically and culturally sustainable riparian landscapes in peri-urban river landscapes can be achieved through the creation of a mosaic of different land uses and restored floodplain sites, accompanied by the establishment of networks and education initiatives to maintain local landscape knowledge and support of the stakeholders.

\section{Acknowledgements}

This study has been financed through a research grant of the first author provided by the State Ministry of Culture, Higher Education and Research, Luxembourg. We would like to thank Tobias Plieninger, Marc Schoellen and two anonymous referees for many valuable comments on the manuscript. We are also grateful to Patrick Schaefer and Anne Caffier for map layout support and to Emily Kilham for improving the language of this paper.

References

[1] Abel, W. (1978). Geschichte der deutschen Landwirtschaft vom frühen Mittelalter bis zum 19. Jahrhundert. Stuttgart: Ulmer.

[2] Administration des Eaux et Forêts (1995). Naturräumliche Gliederung Luxemburgs. Ausweisung ökologischer Regionen für den Waldbau. Luxembourg: Administration des Eaux et Forêts de Luxembourg.

[3] Antrop, M. (2004). Landscape change and the urbanization process in Europe. Landscape and Urban Planning, 67(1-4), 9-26. Doi: 10.1016/S0169-2046(03)00026-4.

[4] Beck, R. (1996). Die Abschaffung der "Wildnis": Landschaftsästhetik, bäuerliche Wirtschaft und Ökologie zu Beginn der Moderne. In Konold, W. [ed.] Naturlandschaft Kulturlandschaft: Die Veränderung der Landschaften nach Nutzbarmachung durch den Menschen (pp. 27-44). Landsberg: Ecomed.

[5] Caruso, G. (2005). Integrating Urban Economics and Cellular Automata to model Periurbanisation. Spatial Dynamics of residential Choice in the Presence of Neighbourhood Externalities. Louvain-la-Neuve: Catholic University of Louvain. 
[6] Centre de Recherche Public (2000). Etude des débits d'étiage dans les bassins-versants de la Syre et de la Wiltz durant l'été 1999. Luxemburg: CRP Gabriel Lippmann.

[7] Decamps, H., Pinay, G., Naiman, R. J., Petts, G. E., McClain, M. E., Hillbricht-Ilkowska, A., Hanley, T. A., Holmes, R. M., Quinn, J., Gibert, J., Tabacchi, A. M. P., Schiemer, F., Tabacchi, E. \& Zalewski, M. (2004). Riparian zones: Where biogeochemistry meets biodiversity in management practice. Polish Journal of Ecology, 52(1), 3-18.

[8] Ehrenfeld, J. G. (2000). Defining the limits of restoration: the need for realistic goals. Restoration Ecology, 8(1), 2-9. Doi: 10.1046/j.1526-100x.2000.80002.x.

[9] Erpelding, E. (1991). Die Mensdorfer Bannmühle. In Choeurs mixtes Sainte Cécile [ed.] Centenaire des Choeurs mixtes Sainte Cécile: 1891-1991 (pp. 79-105). Mensdorf: Choeurs mixtes Sainte Cécile.

[10] Erpelding, E. (1993). Mühle und Landschaft. Letzeburger Zaitschreft fir Kultur, 4, 104-117.

[11] EUROSTAT (1999). Die dicht besiedelten Gebiete in der Europäischen Union: Versuch der Abgrenzung und Charakterisierung der Ballungsräume. Statistik in Kürze. Allgemeine Statistik, Thema 1-2. Luxembourg: EUROSTAT.

[12] Flammang, J. (1991). Die einheimische Landwirtschaft vor 100 Jahren. In Letzeburger Bauerenzentral [ed.] Letzebuerger Bauere-Kalenner (pp. 99-101). Luxembourg: Letzeburger Bauerenzentral.

[13] Fogerty, J. E. (2001). Oral history - a guide to its creation and use. In E.A. Howell [ed.] The Historical Ecology Handbook (pp. 101-120). Washington D.C.: Island Press.

[14] Frisch, J. (1973). Die Entwicklung der Weidenutzung im Laufe des letzten Jahrhunderts in Luxemburg. In Luxemburger Ackerbau- und Viehzuchtgenossenschaft [ed.] Annalen für Ackerbau und Viehzucht (pp. 2-8). Luxembourg: Luxemburger Ackerbau- und Viehzuchtgenossenschaft.

[15] Frisch, J. (2003). Das Genossenschaftswesen in Luxemburg von seinen Anfängen bis heute. In H. Lambert [ed.] Landwirtschaft in Luxemburg - Nostalgie, Alltag, Perspektiven (pp. 111-136). Luxembourg: Ed. Saint-Paul.

[16] Gerecke, R., Stoch, F., Meisch, C. \& Schrankel, I. (2005). Die Fauna der Quellen und des hyporheischen Interstitials in Luxemburg. Ferrantia 41. Luxembourg: Musée national d'histoire naturelle Luxembourg.

[17] Gerlach, R. (1990). Flußdynamik des Mains unter dem Einfluss des Menschen im Spätmittelalter. Trier: Zentralausschuß für deutsche Landeskunde.

[18] Girel, J., Garguet-Duport, B. \& Pautou, G. (1997). Landscape structure and historical processes along diked European valleys: A case study of the Arc/lsère confluence (Savoie, France). Environmental Management, 21(6), 891-907. Doi: 10.1007/s002679900075.

[19] Gonner, N. (1876). Das Luxemburger Land - Seine Geschichte, seine Bewohner, sein Handel und sein Wandel. Luxemburg: Luxemburger Gazette.

[20] Gudermann, R. (2000). Morastwelt und Paradies: Ökonomie und Ökologie in der Landwirtschaft am Beispiel der Meliorationen in Westfalen und Brandenburg (1830-1880). Paderborn: Schöningh.

[21] Haase, D. (2003). Holocene floodplains and their distribution in urban areas - functionality indicators for their retention potentials. Landscape and Urban Planning, 66(1), 5-18. Doi: 10.1016/S0169-2046(03)00071-9.

[22] Haase, D. \& Nuissl, H. (2007). Does urban sprawl drive changes in the water balance and policy? The case of Leipzig (Germany) 1870-2003. Landscape and Urban Planning, 80(12), 1-13. Doi: 10.1016/j.landurbplan.2006.03.011

[23] Hale, B. W. \& Adams, M. S. (2007). Ecosystem management and the conservation of riverfloodplain systems. Landscape and Urban Planning, 80(1-2), 23-33. Doi: 10.1016/j.landurbplan.2006.05.002 
[24] Hamer, P. (1958). Esquisse d'une histoire des voies de communication au Grand-Duché de Luxembourg. In Gerges, M. [ed.] La Moselle. Son passé - son avenir (pp. 33-48). Schwebsingen: Bourg-Bourger.

[25] Hampicke, U. \& Roth, D. (2000). Costs of land use for conservation in Central Europe and future agricultural policy. International Journal of Agricultural Resources, Governance and Ecology, 1(1), 95-108. Doi: 10.1504/IJARGE.2000.006913.

[26] Haslam, S. M. (1991). The Historic River: rivers and culture down the ages. Cambridge: Cobden of Cambridge Press.

[27] Höchtl, F., Rusdea, E., Schaich, H., Wattendorf, P., Bieling, C., Reeg, T. \& Konold, W. (2007). Building bridges and crossing borders: Integrative approaches to rural landscape management in Europe. Norsk Geografisk Tidsskrift - Norwegian Journal of Geography, 61, 157-169. Doi: 10.1080/00291950701709150.

[28] Iaquinta, D. L. \& Drescher, A. W. (2000). Defining Periurban: Understanding Rural-Urban Linkages and Their Connection to Institutional Contexts. In International Rural Sociology Association [ed.] Conference proceedings of the Tenth World Congress of the International Rural Sociology Association, August 1, 2000 (pp. 1-26). Rio de Janeiro: IRSA.

[29] Jessel, B. \& Jacobs, J. (2005). Land use scenario development and stakeholder involvement as tools for watershed management within the Havel River Basin. Limnologica, 35(3), 220-233. Doi: 10.1016/j.limno.2005.06.006.

[30] Joyce, C. B. \& Wade, P. W. (1998). Wet grasslands: a European perspective. In Joyce, C. B. \& Wade, P. M. [eds.] European wet grasslands - biodiversity, management and restoration (pp. 1-12). Chichester: John Wiley \& Sons.

[31] Kohl, M. (1925). Das landwirtschaftliche Genossenschaftswesen des Großherzogtums Luxemburg 1875-1925. Altenburg: Pierer.

[32] Konold, W. (1998). Raum-zeitliche Dynamik von Kulturlandschaften und Kulturlandschaftselementen - Was können wir für den Naturschutz lernen? Naturschutz und Landschaftsplanung, 30(8/9), 279-284.

[33] Konold, W. (2005). Mensch und Fließgewässer - Frühe Nutzungen. In Jürging, P. \& Patt, $\mathrm{H}$. [eds.] Fließgewässer und Auenentwicklung - Grundlagen und Erfahrungen (pp. 47-62). Berlin, Heidelberg, New York: Springer.

[34] Konold, W. (2007). Die wasserabhängigen Landökosysteme. Gibt es gemeinsame Strategien von Wasserwirtschaft und Naturschutz zu deren Schutz und Erhalt? Hydrologie und Wasserbewirtschaftung, 51, 257-266.

[35] Konsbruck, G. (1970). Les principaux Cours d'eau et la Navigation de Départment des Fôrets (1795-1814). Luxembourg.

[36] Kreins, J.-M. (1996). Histoire du Luxembourg: des origines à nos jours. Paris: Press Universitaires de France.

[37] Large, A. R. G. \& Petts, G. E. (1996). Historical channel-floodplain dynamics along the River Trent - Implications for river rehabilitation. Applied Geography, 16(3), 191-209. Doi: 10.1016/0143-6228(96)00004-5

[38] Letzeburger Sportfescher (1955). De Letzeburger Sportfescher. Luxembourg: Letzeburger Sportfescher.

[39] Marcucci, D. J. (2000). Landscape history as a planning tool. Landscape and Urban Planning, 49(1-2), 67-81. Doi: 10.1016/S0169-2046(00)00054-2.

[40] Mata Olmo, R. \& Muñoz, F. (2004). La Huerta de Murcia: landscape guidelines for a periurban territory. Landscape Research, 29(4), 385-397. Doi: 10.1080/0142639042000289028.

[41] Mitchell, C. J. A. (2004). Making sense of counterurbanization. Journal of Rural Studies, 20(1), 15-34. Doi: 10.1016/S0743-0167(03)00031-7. 
[42] Müller, J. (2005). Biotope aus Menschenhand - Biotope und Strukturen als Ergebnis extensiver Nutzung. München: Elsevier - Spektrum Akademischer Verlag.

[43] Nassauer, J. I. (1997). Cultural sustainability: aligning aesthetics and ecology. In J. I. Nassauer [ed.] Placing Nature (pp. 65-83). Washington DC: Island Press.

[44] Nicolay, J. (1938). Bauern und Landwirtschaft in der Geschichte des Luxemburger Landes von 1815 bis in unsere Zeit. Luxembourg:

[45] Parker, D. J. (1995). Floodplain Development Policy in England and Wales. Applied Geography, 15(4), 341-363. Doi: 10.1016/0143-6228(95)00016-W.

[46] Paul, M. J. \& Meyer, J. L. (2001). Streams in the urban landscape. Annual Review of Ecology and Systematics, 32, 333-365. Doi: 10.1146/annurev.ecolsys.32.081501.114040.

[47] Pfadenhauer, J. (2001). Some remarks on the socio-cultural background of restoration ecology. Restoration Ecology, 9(2), 220-229. Doi: 10.1046/j.1526-100x.2001.009002220.x.

[48] Piégay, H. \& Salvador, P.-G. (1997). Contemporary floodplain forest evolution along the middle Ubaye River, Southern Alps, France. Global Ecology and Biogeography Letters, 6(1), 397-406. Doi: 10.1046/j.1365-2699.1999.00316.x.

[49] Poschlod, P. \& Wallis de Vries, M. F. (2002). The historical and socioeconomic perspective of calcareous grasslands - lessons from the distant and recent past. Biological Conservation, 104(3), 361-376. Doi: 10.1016/S0006-3207(01)00201-4

[50] Pykälä, J. (2000). Mitigating human effects on European biodiversity through traditional animal husbandry. Conservation Biology, 14(3), 705-712. Doi: 10.1046/j.15231739.2000.99119.x.

[51] Renes, J. (2004). Different methods for the protection of cultural landscapes - the example of an early industrial landscape in the Veluwe region, The Netherlands. Palang, $\mathrm{H}$., Sooväli, H., Antrop, M. \& Setten, G. [eds.] European Rural Landscapes: Persistence and Change in Globalising Environment (pp. 333-344). Dordrecht: Kluwer Academic Publishers.

[52] Rohde, S., Hostmann, M., Peter, A. \& Ewald, K. C. (2006). Room for Rivers: An integrative search strategy for floodplain restoration. Landscape and Urban Planning, 78(1-2), 50-70. Doi: 10.1016/j.landurbplan.2005.05.006.

[53] Schaich, H. (2009). Local residents' perceptions of floodplain restoration measures in Luxembourg's Syr Valley. Landscape and Urban Planning, 93(1), 20-30. Doi: 10.1016/j.landurbplan.2009.05.020.

[54] Schaich, H., Rudner, M. \& Konold, W. (2010). Short-term impact of river restoration and grazing on floodplain vegetation in Luxembourg. Agriculture Ecosystems \& Environment, 139(1-2), 142-149. Doi 10.1016/j.agee.2010.07.012.

[55] Schmithüsen, J. (1940). Das Luxemburger Land - Landesnatur, Volkstum und bäuerliche Wirtschaft. Forschungen zur Deutschen Landeskunde Band 34. Leipzig: Hirzel.

[56] Schnitter, N. (1992). Die Geschichte des Wasserbaus in der Schweiz. Zürich: Olynthus.

[57] Schwineköper, K. (2000). Historische Analyse. In Konold, W., Böcker R. \& Hampicke, U. [eds.] Handbuch Naturschutz und Landschaftspflege (pp. IV-10, 11-23). Landsberg: Ecomed.

[58] SER (2004). The SER International Primer on Ecological Restoration. Tucson: Society for Ecological Restoration International.

[59] Statec, 2007. Portail des Statistique de Luxembourg. Statec.

[60] Swart, J. A. A., Van der Windt, H. J. \& Keulartz, J. (2001). Valuation of nature in conservation and restoration. Restoration Ecology, 9(2), 230-238. Doi: 10.1046/j.1526100x.2001.009002230.x. 
[61] Swetnam, T. W., Allen, C. D. \& Betancourt, J. L. (1999). Applied historical ecology: Using the past to manage for the future. Ecological Applications, 9(4), 1189-1206. Doi: 10.1890/1051-0761(1999)009.

[62] Tockner, K. \& Stanford, J. A. (2002). Riverine flood plains: present state and future trends. Environmental Conservation, 29(3), 308-330. Doi: 10.1017/S037689290200022X.

[63] Tracy, M. (1989). Government and Agriculture in Western Europe 1980-1988. Hertfordshire: Harvester Wheatsheaf.

[64] Trossen, M. (1997). Chronik der Pfarrei Schüttringen-Hostert sowie der Höfe Anven und Schittringen. Schuttrange: Gemeinde Schüttringen.

[65] Van Werveke, N. (1983). Kulturgeschichte des Luxemburger Landes. Esch-sur-Alzette: Hury.

[66] Vandermeulen, V., Verspecht, A., Van Huylenbroeck, G., Meert, H., Boulanger, A. \& Van Hecke, E. (2006). The importance of the institutional environment on multifunctional farming systems, in the peri-urban area of Brussels. Land Use Policy, 23(4), 486-501. Doi: 10.1016/j.landusepol.2005.06.002.

[67] Ward, J. V., Trockner, K., Arscott, D. B. \& Claret, C. (2002). Riverine landscape diversity. Freshwater Biology, 47(4), 517-539. Doi: 10.1046/j.1365-2427.2002.00893.x.

[68] Wohl, E. (2005). Compromised rivers: understanding historical human impacts on rivers in the context of restoration. Ecology and Society, 10(2), 2.

[69] Zasada, I., Fertner, C., Piorr, A. \& Nielsen, T. S. (2011). Peri-urbanisation and multifunctional adaptation of agriculture around Copenhagen. Geografisk Tidsskrift-Danish Journal of Geography, 111(1), 59-72. 